\title{
A study on detainees: Effects of war on health and rights
}

\author{
Janaki Warushahennadi ${ }^{1}$, W.N.S.Perera' ${ }^{2}$ P.Paranitharan ${ }^{2}$
}

${ }^{I}$ Senior Lecturer, Department of Forensic Medicine, Faculty of Medicine, Karapitiya

${ }^{2}$ Senior Lecturer, Department of Forensic Medicine, Faculty of Medicine, Ragama

\section{ABSTRACT}

The recently concluded 'war' in Sri Lanka has cost thousands of lives and disabled many people. A proportion of the disabled people and some able men and women are still languishing in detention centers awaiting retribution for their suspected crimes. Since most of them are "hardcore LTTE cadres", 'human rights' activists keep continuous vigil on them to see whether they are maltreated. Medico-legal examinations are routinely performed on them in the following occasions, immediately after taking into custody, prior to release into the community and before and after confession.

A retrospective study was carried out on 50 cases by reviewing Medico Legal documents of detainees who have been referred for medicolegal examination.

Out of 50 cases analyzed majority (98\%) of the detainees were young males with mean age of $351 / 2$ years and from the Northern Province. Most of them had participated in war (74\%) and having consequences of war related injuries. $94 \%$ of them were detained for more than 3 months in the detention camp and almost all of them didn't declare ill treatment during their detention. There were no convicted individuals in the sample population.

There are severe effects of war injuries on detainees such as amputated extremities (4\%), post traumatic epilepsy (10\%) and multiple scars following shrapnel or firearm injuries (58\%). They do not complain on mal treatment while in detention. However due process of trial is needed as early as possible to safeguard their rights.

\section{INTRODUCTION}

The recently concluded war in Sri Lanka had cost thousands of lives and disabled many people ${ }^{1}$ A proportion of the disabled people and some able men and women are still languishing in detention centers awaiting retribution for their suspected crimes. Being LTTE cadres they had been arrested under the Prevention of Terrorism Act ${ }^{2}$ months or years ago, before they are produced for medico-legal examination. Under this act a person can be kept in custody without producing before a judge for many months. ${ }^{2}$ Naturally human rights activists keep constant vigil on them as they are prone to be maltreated by their keepers.

Laws of detention are different from country to country depending on their requirements. The state of Israel use administrative detention of terror suspects to keep in custody for a long period. ${ }^{3}$ Indefinite detention of an individual occurs frequently in wartime under the laws of war ${ }^{4}$; this has been applied by the United States after the September 11, 2001 attacks. ${ }^{4}$

According to the Universal declaration of human rights, a person cannot be subjected to an arbitrary arrest, detention, or imprisonment. ${ }^{5,},{ }^{6}$ This may not be a case in countries where acts of terrorism is rampant. Detention is seen as 'arbitrary' when there is no legal basis for detention or there are grave violations of the right to a fair trial. However, there is possibility of having disparity between the country's laws ${ }^{2}$ with the international standards. According to the international human rights law, all defendants have the right to a fair trial and treatment. ${ }^{56}$ 
However, in many countries throughout the world, detainees are held without due process and convicted in trials where these safeguards have been ignored. ${ }^{7}$ In some instances people are held for long periods without trial, they are subjected to torture to acquire information or confession. Despite prevalent international criticism US naval base in Guantánamo Bay, hundreds of people from 30 nationalities have been detained without charge $^{6}$

Medico-legal examinations are routinely performed on detainees of Liberation Tigers of Tamil Eelam (LTTE) suspects immediately after taking into custody, prior to release into the community or before and after confession. They are evaluated for health condition, scars, injuries and for possible actions of torture while on custody. Therefore this study highlights the need of further evaluation of situation to understand the magnitude and diversity of the problems related to their health and rights to provide better care for them.

\section{OBJECTIVES:}

To assess the socio-demographic details, effects of war on health and violation of rights of the detainees of war

\section{STUDY DESIGN}

A retrospective study was carried out on detainees who have been referred for medicolegal examination at the Department of Forensic Medicine, Faculty of Medicine, Karapitiya from Boosa camp over 6 months period in 2012. Investigator's Medico Legal documents of 50 detainees were reviewed and the data was extracted into a data sheet including demographic details, health condition, and history of ill treatment mentioned by the detainee. Data was analyzed using the Statistical Package for Social Sciences (SPSS).

\section{RESULTS \\ CHARACTERISTICS OF DETAINEES}

Demographic details of the 50 detainees were evaluated in this study. Among the total there were 49 males and 1 female with the mean age of $351 / 2$ years. (range of 18-45 years) Majority of them had their secondary education (96\%), married (62\%) with children (54\%), either from north $(62 \%)$ or eastern $(32 \%)$ provinces and the rest from upcountry estates. $(6 \%)$

\section{DURATION AND REASON FOR DETENTION}

$94 \%$ of them were in detention camp for more than 3 months and $6 \%$ for less than 3 months. While $52 \%$ of them detained without a trial for more than a year. According to the history given by detainees most of them had actively participated in war $(60 \%)$ as LTTE carders. Only $6 \%$ of them claimed this as an arbitrary arrest. (Table 1)

Table: 1

\begin{tabular}{|c|c|c|c|}
\hline & & Number & Percentage \\
\hline \multicolumn{4}{|c|}{ Duration of detention } \\
\hline & $<1$ month & 02 & $04 \%$ \\
\hline \multicolumn{2}{|r|}{1 month -3 months } & 01 & $02 \%$ \\
\hline & $>3$ months -1 year & 21 & $42 \%$ \\
\hline \multicolumn{2}{|r|}{$>1$ year } & 26 & $52 \%$ \\
\hline \multirow[t]{5}{*}{ Reason for arrest } & Suspected as LTTE carder & 09 & $18 \%$ \\
\hline & Surrender $\mathrm{him} / \mathrm{her}$ self & 07 & $14 \%$ \\
\hline & Arbitrary arrest & 03 & $06 \%$ \\
\hline & Involved in war act and arrested & 30 & $60 \%$ \\
\hline & other & 01 & $02 \%$ \\
\hline
\end{tabular}

MEDICO LEGAL EXAMINATION OF DETAINEES

During their period of detention, (92\%) of them were examined by Judicial Medical officer (JMO) following arrest. There were other reasons to be produced before JMO such as before release $(02 \%)$ and before confession $(06 \%)$. 
Table: 2

\begin{tabular}{|llcc|}
\hline \multicolumn{1}{ll}{} & \multicolumn{1}{c}{ Number } & percentage \\
\hline Previous examination by JMO & yes & 03 & $06 \%$ \\
\hline & no & 47 & $94 \%$ \\
\hline $\begin{array}{l}\text { Reason for recent medico Legal } \\
\text { examination }\end{array}$ & After arrest & 46 & $92 \%$ \\
& $\begin{array}{l}\text { Before release } \\
\text { Before } \\
\text { confession }\end{array}$ & 01 & $02 \%$ \\
& & 03 & $06 \%$ \\
\hline
\end{tabular}

\section{HEALTH CONDITION OF DETAINEES}

Among natural illnesses, bronchial asthma was the most common disease (20\%) and considerable numbers of multiple scars $(70 \%)$ which were consistent with those caused by either shrapnel or bullet injuries were detected. Post traumatic epilepsy was reported in $10 \%$ of cases based on available medical reports.

Table: 3

Number Percentage

\begin{tabular}{|c|c|c|c|}
\hline \multicolumn{4}{|l|}{$\begin{array}{l}\text { Health } \\
\text { conditions }\end{array}$} \\
\hline Natural illness & Hypertension/ ischemic heart disease & 04 & $08 \%$ \\
\hline \multicolumn{2}{|r|}{ Bronchial asthma } & 10 & $20 \%$ \\
\hline & Other chronic illness & 02 & $04 \%$ \\
\hline $\begin{array}{l}\text { War injuries and } \\
\text { effects }\end{array}$ & No evidence of war injuries & 15 & $30 \%$ \\
\hline \multicolumn{2}{|r|}{ Evidence of war injuries } & 35 & $70 \%$ \\
\hline & - Amputation of leg & 02 & $04 \%$ \\
\hline \multicolumn{2}{|r|}{ - Post traumatic epilepsy } & 05 & $10 \%$ \\
\hline & $\begin{array}{l}\text { - Multiple scars of shell injury or } \\
\text { fire arm }\end{array}$ & 29 & $58 \%$ \\
\hline
\end{tabular}

15 detainees were on medical treatment for their illnesses or trauma however 3 mentioned that they were not on treatment even though they had some ailment but not seeking any medication from prison authorities. Two of them are using their own inhalers and one was found to be hypertensive and referred for further medical action. History of any ill treatment during detention was not declared to the JMO by any of the detainees and medical evidence of ill treatment was not detected at the time of examination. In half of the cases relatives are aware on their detention, however only $1 / 3$ of them were visited by a relative.

Table: 4

\begin{tabular}{lllc}
\hline & & Number & percentage \\
\hline On medical care for illnesses & yes & 15 & $30 \%$ \\
& no & 03 & $06 \%$ \\
\hline History of ill treatment during detention & yes & - & - \\
& no & 47 & $94 \%$ \\
\hline Relatives are aware on detention & Not sure & 01 & $02 \%$ \\
\hline & yes & 25 & $50 \%$ \\
\hline Relatives visited & no & 01 & $02 \%$ \\
\hline & Details not available & 24 & $48 \%$ \\
& Yes & 08 & $16 \%$ \\
\hline & no & 15 & $30 \%$ \\
\hline & Details not available & 17 & $43 \%$ \\
\hline
\end{tabular}

\section{DISCUSSION}

The findings of this study indicate that majority of the detainees were young males and they are from the Northern Province. It is no secret that seeds for terrorism were initially planted in the Northern Province and more youth were attracted following an ideology of living in a separate state. But what is so disturbing is most youth who have received a secondary education and instead of pursuing a job oriented carrier they were attracted towards terrorist activities. Most of them are married and it may be interpreted that marriage had become no barrier in continuing their idealistic beliefs. Therefore the determination to engage in activities which are considered unlawful in a country and would definitely result in jail sentences had not been hampered by other social values such as education, marriage and personal ambitions.

When we analyse the general physical fitness by way of checking for and debilitating medical illnesses we found that considerable number of them are suffering from Bronchial Asthma (10\%) and from effects of war injuries $(70 \%)$ such as post traumatic epilepsy and amputations. In addition to that substantial number of them had multiple deep scars causing 
disfiguration and incapacitation. Majority of the detainees were on treatment for their medical illnesses except a few. Severe effects of war injuries make serious health burden to themselves, to family and relatives and to the community as a whole. ${ }^{8}$

The data available from the history and examination show possibility of most of them had a link with the LTTE organization. While in detention, they were subjected to a JMO examination. In Sri Lanka, the JMO's are considered as an independent Forensic examiner to whom the detainees can express their concerns without the presence of the police or prison officers at the time of examination. This is the accepted practice except in situations where the prisoner is considered a threat to the examining doctor. Therefore providing an opportunity to be examined by JMO in fact can be considered as granting or fulfilling a medico legal right. Further keeping the relative informed about their whereabouts is also a legal right that had been taken place in nearly half of the inmates. Though the relatives were informed, the majority of them could not visit them while in detention. This could have happened due to several reasons. The language barrier and the distance they have to travel from the northern and eastern provinces would have hindered the visits. Further the financial constraints also can play a role other than many social reasons.

The majority of scars observed in the detainees were most likely due to involvement of direct combat activities which is to a greater extent compatible with the given history and examination findings. There were no injuries or scars that they attributed to torture. None of them had complained about ill treatment during detention. Eventhough there is no complains on maltreatment by authorities further studies are needed to assess the awareness of their rights by the detainees.

Further we feel the necessity of their cases to be expedited since many of them are being detained without a trial for more than one year.

\section{LIMITATIONS}

It is likely that the outlook on violation of rights of the detainees are underestimated in this study because of some of the information such as availability of lawyers, general facilities, recreational facilities, and counseling cannot be gathered in a retrospective study.

\section{CONCLUSIONS}

The study revealed a healthy outlook of the detainees, if we consider the statements they gave to the examining doctor are true and the physical examination revealed only injuries sustained during the combat period. There were no reported incidents of torture. However a proper detailed psychological assessment of each individual together with an education about their rights to which they are entitled would further enhance the reliability of this study. Those who are detained without a trial for more than 1 year needs immeadiate consideration by the legal authorities.

\section{References:}

1. Report of the commission of inquiry on lessons learnt and reconciliation, November 2011

2. Prevention of Terrorism act No 48 of 1979

3. A Reexamination of Administrative Detention in a Jewish and Democratic State .Elad Gil, Mordechai Kremnitzer, 2011

4. Boulden, Jane; Weiss, Thomas George (2004). Terrorism and the UN: before and after September 11. Indiana University Press. p. 57. ISBN 978-0-253-21662-5.

5. Universal declaration of human rights (art. 1), adopted by general assembly resolution 217 a (iii) of 10 December 1948.

5. Geneva Convention relative to the Treatment of Prisoners of War, 75 U.N.T.S. 135

6. Leigh, David; Ball, James; Burke, Jason (25 April 2011). "Guantánamo files lift lid on world's most controversial prison". The Guardian (UK)

7. Lynn L., Chen J. Prevalence of war related sexual violence and other related abuses among internally displaced persons, JAMA International

\section{Acknowledgement} analysis

Dr. B. Manjula Priyadarshani for data

\section{Declaration}

We wish to declare that part of this study was presented for poster presentation at the $12^{\text {th }}$ Academic sessions of College of Forensic Pathologists of Sri Lanka 2013. 